\title{
Measuring the contributions of Catholic schools globally
}

\author{
Quentin Wodon
}

\section{Introduction}

About two and a half years ago, I had the opportunity to meet Professor Gerald Grace for the first time in Rome. We both participated in a conference on Catholic education organised by the University of Notre Dame and were on the same panel. Right after the panel, he asked me to draft an article for the journal he had created a decade earlier - International Studies in Catholic Education (ISCE). His request was for me to use some of the data I had compiled from household surveys and other sources to provide a quantitative assessment of the extent to which Catholic schools were reaching the poor in Africa. The issue of whether Catholic schools were successful in reaching the poor was one that he deeply cared about. More generally, his intent was to promote robust empirical work on the contribution of Catholic schools, given that much of the existing literature tended to be conceptual or theological, or based on small datasets. He felt that if the contributions of Catholic schools to students and their families, as well as communities and societies, were to be better recognised, they had to be documented quantitatively using robust, nationally representative data. Over the last two years, he has encouraged me to pursue work in this area, especially in developing countries where fewer studies have been conducted so far on Catholic schools than is the case in high-income countries.

The second time I met Professor Grace was in London a year later, again thanks to a conference on Catholic education organised by the University of Notre Dame. I have two vivid memories of Professor Grace from that week. The first memory is when he asked to comment on one of the issues being discussed at the conference, and therefore needed the microphone. A friend of his brought the microphone on a small red cushion (if I recall properly) and gave it to him saying 'Your Grace'! This was a playful mark of respect not only for Professor Grace's ability to inject crucial substance into virtually any discussion, but also for the way in which he did so, using an orator speaking style that was reminiscent of a previous era. Combined with his vast knowledge and the fact that he was always impeccably dressed, you had the feeling of being in the presence of a type of scholarship that has become rare these days. A second memory from that

DOI: $10.4324 / 9781003|7| 553-14$ 
same week is when I gave a lecture at Saint Mary's University Twickenham (London) at Professor Grace's invitation. He simply organised everything with perfection, from the choice of the venue (the Senior Common Room) which was beautiful, to his introductory remarks and the reception afterwards. He even went through the trouble of dropping me back by car in London at my hotel after the event. Truly, he was a wonderful host. Apart from his scholarship, his personal qualities and the friendship he extended to others, this, I suspect, is also a reason why his work on Catholic education has been so influential internationally. He is also generous with his time - when I asked him to answer a few questions for an interview for the Educatio Si Bulletin that I am co-editing for the International Office for Catholic Education (Office International de l'Enseignement Catholique or OIEC $^{1}$ in French), he agreed right away (Grace, 2020).

As I thought about the focus of a chapter for this Festschrift, I faced a bit of a dilemma in terms of the choice of topic to focus on. Should I try to write an essay on some of the areas that Professor Grace worked on himself, and in particular the concept of spiritual capital (e.g., Grace, 2002a, 2002b)? Or should I focus more on some of the areas on which he thought I might be able to contribute some new insights because of my training as an applied economist? As I am still very much of a novice in the field of research on Catholic education, I feel that I do not yet have the depth of knowledge needed to tackle properly the 'big issues' related to the identity of Catholic schools, how to foster spiritual capital, ${ }^{2}$ and how to build 'fraternal humanism', to borrow the term used by the Congregation for Catholic Education (2017). So allow me to focus on the area on which I have done more work - trying to measure, albeit imperfectly, some of the contributions of Catholic schools globally. This is in fact also an area in which Professor Grace was a pioneer, including through the comparative analysis of Catholic education he provided in his two-volume handbook on international Catholic education (Grace and O'Keefe, 2007).

Rather than focus on any one particular contribution of Catholic schools globally, it seems more useful for a Festschrift to go a bit broader, and provide an overview on the topic at hand. For this reason, the analysis in this chapter is adapted from the first chapter of the Global Catholic Education Report (Wodon, 2020a) I wrote recently for OIEC. This analysis has not been published formally in book format, so I thought it might be appropriate to include it in this Festschrift, especially since Professor Grace encouraged me to work in this area. For this chapter, I updated the data on enrolment trends to reflect the latest available data from the Secretariat of State of the Vatican (2020), reorganised some of the components of the analysis, and shortened it to fit within the allocated word limit. Finally, in the conclusion, I added a few personal thoughts on the inspiration that we can all derive from Professor Grace's leadership in this field of research.

The main message from this chapter is that Catholic schools contribute in a very significant way to achieving the fourth of the Sustainable Development Goals (SDGs) - ensuring inclusive and equitable quality education and promoting lifelong learning opportunities for all. To show how this is the case, I 
will first document trends in enrolment in Catholic schools using data from the annual statistical yearbooks of the Church. Thereafter, I will discuss some of the specific contributions made by Catholic schools that benefit students and their families, as well as communities and broader societies. Finally, in my conclusion, I will briefly mention some of the concerns that are emerging from the COVID-19 crisis.

\section{Trends in enrolment}

Data on the number of students in K12 Catholic schools are available in the Catholic Church's annual statistical yearbooks, with the most recent data available for $2018 .^{3}$ The yearbooks provide data by country on enrolment in K12 schools by level, considering separately preschools, primary schools, and secondary schools for each country and some territories. Data are also provided for enrolment in institutions of higher learning, but this is not considered in this chapter (for trends in enrolment at the tertiary level, see Wodon, 2020b; for a more detailed analysis of K12 trends, see Wodon, 2018a).

Figures 11.1 through 11.4 provide estimates of enrolment in Catholic schools for preschools, primary schools, and secondary schools, as well as total enrolment for all three levels combined. Trends are visualised for five regions: Africa, the Americas, Asia, Europe, and Oceania. The analysis is kept at that level to keep the figures manageable, but data are available at the country level in the statistical yearbooks as well as in the statistical annex of the Global Catholic Education Report 2020 (in that report with data over time in five-year intervals up to 2017). For primary and secondary schools, data are provided in Figures 11.2 and 11.3 from 1975 to 2018. For preschools, data are not available for 1975, so the series starts in Figure 11.1 in 1980. More detailed breakdowns for sub-regions could be constructed, but the regions included in the figures are sufficient to establish stylised facts on broad trends in enrolment globally and regionally.

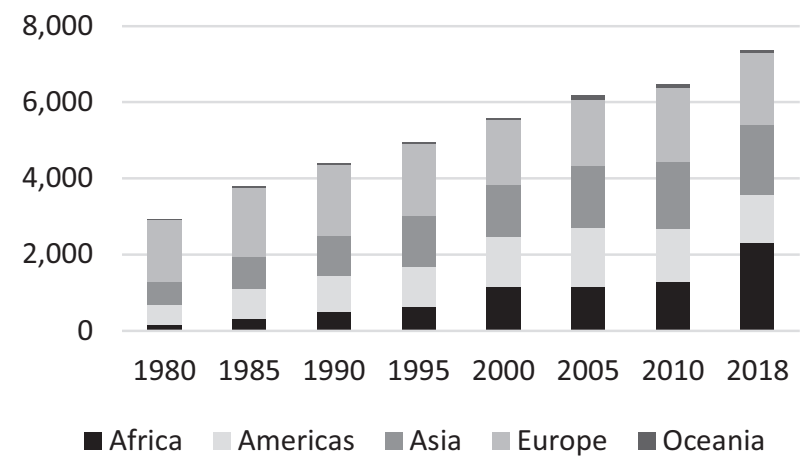

Figure II.I Enrolment in Catholic preschools (thousands) 


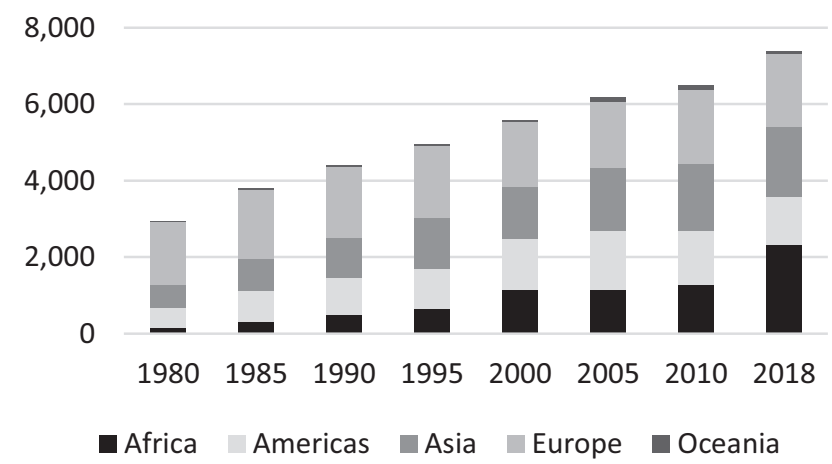

Figure II.2 Enrolment in Catholic primary schools (thousands)

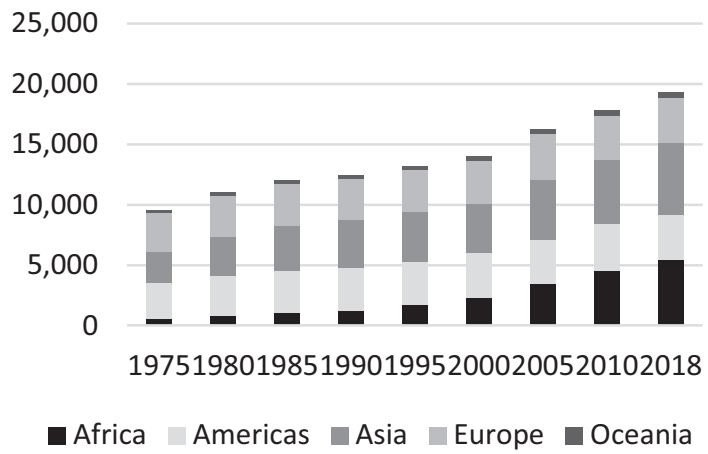

Figure II.3 Enrolment in Catholic secondary schools (thousands)

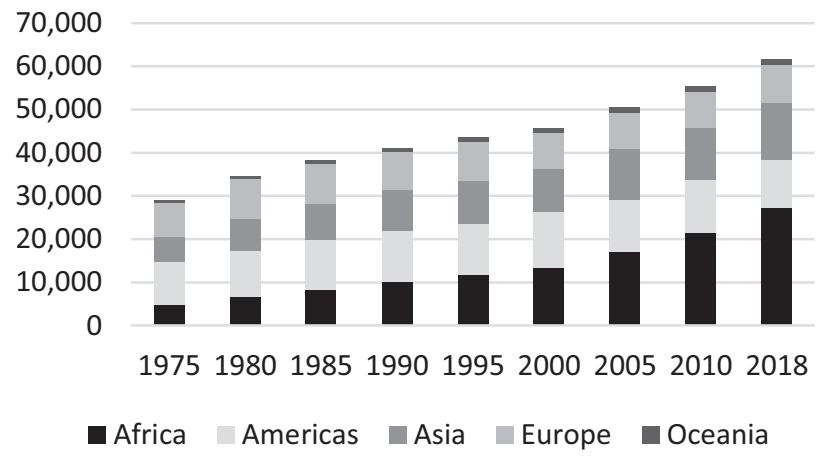

Figure II.4 Total enrolment in Catholic K12 schools (thousands) Note: Preschools not included in 1975

Source: Statistical Yearbook of the Church 
In 2018, according to the latest statistical yearbook, 7.4 million children were enrolled in Catholic preschools globally, 35.0 million children attended primary schools, and 19.3 million children attended secondary schools, for a total across the three levels of more than 62.1 million children. Overall, the Church managed more than 100,000 primary schools, close to 50,000 secondary schools, and over 70,000 preschools. In some countries such as India that are large and complex, estimates of enrolment in Catholic schools could be on the low side due to the difficulty of collecting comprehensive data from multiple organisations managing Catholic schools beyond Dioceses. While additional work could be conducted at the country level to check estimates with other data sources country by country, this would be a major undertaking beyond the scope of this chapter.

Despite necessary caution about the data, a number of stylised facts emerge. First, trends in enrolment suggest healthy growth over time. Total enrolment in K12 education more than doubled between 1975 and 2018 globally, from 29.1 million to 62.1 million students. Most of the growth was concentrated in subSaharan Africa. This is not surprising, given the region's high rate of population growth and its gains in enrolment thanks to the 'education for all initiative'. As a result, by 2018, the Africa region had 27.2 million children enrolled in Catholic K12 schools. Of those, 19.4 million were in primary schools. This accounted for 55.1 percent of all children enrolled in Catholic schools at that level globally. The other region with a large increase in enrolment in absolute terms over time is Asia, mostly due to gains in India, especially at the secondary level.

Second, there are differences between regions in the share of students by level. Globally, primary schools account for 56.22 percent of total enrolment in K12 Catholic schools in 2018, versus 32.1 percent for secondary schools, and 11.7 percent for preschools. In Africa, however, primary schools still account for 71.3 percent of total enrolment, mostly because the transition to secondary schools is still weak in many countries (only four in ten students in sub-Saharan Africa complete their lower secondary school according to the World Bank's World Development Indicators). Globally, there has been a progressive decline in the share of students enrolled at the primary level globally given gains in educational attainment and more opportunities for children to benefit from preprimary education.

Third, in proportionate terms, as a percentage change from the base, the highest growth rates are observed for Africa, as was the case for absolute gains in enrolment. But growth rates are also high in Asia and Oceania. By contrast, in the Americas (and especially the US) and in Europe, growth rates tend to be much smaller, and in some cases are negative. If those trends continue, Africa will represent in the future an even larger share of all students enrolled in Catholic schools globally (Wodon, 2019a).

Fourth, the share of students enrolled in Catholic schools globally has remained somewhat stable over time. To compute this share, estimates of enrolment in 
Catholic schools can be compared to data on the total number of pupils enrolled in school from the UNESCO Institute of Statistics. This can be done for primary and secondary schools as data for preschool enrolment are less reliable. Globally, just under five percent of all students at the primary level are enrolled in Catholic schools. For secondary school, the proportion is a bit smaller. Over time, this share has decreased slightly at the secondary level, but it has increased slightly at the primary level. In Africa, however, these shares are much higher.

Fifth, there is a lot of heterogeneity between countries in the size of their Catholic school networks. Together, the top 15 countries in terms of enrolment in K12 Catholic schools account for about two-thirds of global enrolment. Enrolment is largest in absolute terms in India due in part to the sheer size of the country. But many of the other countries with large enrolment are from sub-Saharan Africa, including the Democratic Republic of Congo, Uganda, Kenya, and Malawi. Three of these four countries are classified as low income by the World Bank, with Kenya classified as lower-middle income, as is the case of India. In other words, many of the largest Catholic school networks are located in countries with substantial poverty, contributing to the mission of Church to serve the poor.

Sixth, the fact that the highest growth rate in enrolment over the last four decades is observed for preschools is good news. Early childhood is a critical period in the life of children and investments at that age tend to have high returns. This is the case especially for the first 1,000 days in the life of children when brain development occurs, but also later, including to make sure that children are ready to enter primary school (Black et al., 2017). Early stimulation and preschools are among key programmes that governments should promote to invest in human development (Denboba et al., 2014).

\section{Contributions to education systems}

By enrolling 62.1 million students globally, Catholic schools clearly make a contribution to education systems in the countries where they operate. But what about the quality of the education being provided? It is often believed that Catholic schools perform comparatively well in terms of learning outcomes. In the United States where much of the research has been conducted, multiple studies have suggested positive outcomes for students attending Catholic schools (see among others Coleman et al., 1982; Greely, 1982; Coleman and Hoffa, 1987; Bryk et al., 1993; Evans and Schwab, 1995; Evans et al., 1995; Sander and Krautman, 1995; Sander, 1996; Neal, 1997; Altonji et al., 2005; Carbonaro, 2006; Hallinan and Kubitschek, 2013; and Freeman and Berends, 2016). Whether the schools themselves perform better than other types of schools remains debated, and a few studies have suggested that this may not be the case (see for example Jepsen, 2003; Elder and Jepsen, 2014). Yet overall, the evidence points to a Catholic school advantage possibly linked to core values espoused by the schools such as an emphasis on the community, high 
expectations for students, and a concern for social justice leading schools to reach out to low-income and minority students. In developing countries, the evidence on the performance of Catholic schools is less extensive in part due to lack of data, although there are exceptions. Yet, it cannot be denied that in many countries there is a strong demand from parents for a Catholic education related at least in part to a perception of academic strength.

The ability of Catholic schools to empower principals and create a positive school culture may be one of the reasons why they seem to perform well. ${ }^{4}$ This relates to conditions for school autonomy and accountability emphasised in the literature (Demas and Arcia, 2015). The importance of school leadership and management can be illustrated with the case of Fe y Alegría schools in Latin America (Wodon, 2019b). Evidence in Peru suggest that the schools perform well (Lavado et al., 2016). See also the essays in Parra Osorio and Wodon (2014). According to focus groups and interviews (Osorio and Wodon, 2014), factors contributing to the good performance of Fe y Alegría schools include a high degree of independence at the school level for generating and managing resources, a favourable institutional climate, an emphasis on the proper selection, tutoring, supervision, and training of teachers, autonomy and authority for school principals, and the capacity to adapt to local realities. Principals convey 'the mission of the schools' in order to engage students, teachers, and the whole community. Fe y Alegría teachers are motivated by the sense of purpose they witness in the schools and experienced teachers enjoy the opportunity to coach and mentor younger teachers. These various elements of the culture of the schools are mutually reinforcing, leading to better teaching and student learning.

\section{Contributions to communities}

As mentioned earlier, Catholic schools and the Church more generally have a long tradition of serving the poor (e.g. Pontifical Council for Justice and Peace, 2004; Francis, 2015; McKinney, 2018). Today, implementing the preferential option for the poor is challenging for many schools. Congregations which used to be able to provide quasi-free education a few decades ago may no longer have the personnel and resources to do so today. In the absence of state support, cost recovery may lead the schools to be unaffordable for the very poor. These pressures are unlikely to change, and may become more severe. One of the ways to reach the poor is to locate schools in poor areas, but this is not necessarily where new schools are being built (Wodon, 2020c). Still, even if Catholic schools are not primarily serving the poor today as is the case for most other types of schools, they do reach millions of children in poverty (on sub-Saharan Africa, see Wodon, 2014, 2015, 2019c, 2020d).

Catholic and other faith-based schools also provide options for parents, thus contributing to healthy pluralism in the educational choices available to them. One benefit is that parents may be more comfortable with faith-based schools for their adolescent girls (Gemignani and Wodon, 2017; see also Gemignani et al., 
2014, on parental perceptions of schools.). Another benefit relates to the concepts of integral growth or integral human development used in Catholic social thought to refer to the growth of the whole person, including in terms of the values that the person acquires. By emphasising those aspects, even if the evidence to that effect remains limited, Catholic schools may help build stronger communities with higher levels of civic participation from their members.

Education systems should help children to become engaged citizens who are respectful of others and of the earth. This was recognised in Article 29 of the Convention on the Rights of the Child (on the crucial importance of the right to education for other human rights and the Sustainable Development Goals, see Wodon, 2019g). It is also recognised by most school networks, whether of public, private, secular or faith-based nature. What exactly the call for promoting values and character education in educational systems entails may differ depending on the school system considered. But respect for others and for pluralism (which does not imply relativism) should be one of the core values being taught.

According to the Congregation for Catholic Education (2017), Catholic schools should strive towards the development of a person's psychological and moral consciousness. The Congregation defines 'a school as a place where integral formation occurs through a living encounter with a cultural inheritance'. Given the pluralism that characterises today's societies and the fact that many students in Catholic schools are not Catholic, the Congregation calls for an education that leads to 'fraternal humanism and a civilization of love' (p. 532). Ensuring that education is provided 'in a Catholic key' should be a key aim of Catholic schools (DelFra et al., 2018). Such an education is based on a personal encounter with others who pass on faith and wisdom; it is sacramental, permeated by an intentional culture; it is Eucharistic in affirming the communal nature of the person; and it is unitive, combining faith and reason. When they are successful, the schools create an environment that fosters not only academic excellence, but also spiritual growth - for children who are Catholics and those who are not, so that all can pursue their own journey towards the fullness of human flourishing. The respect for faith, including other faiths than the Catholic faith, and the emphasis on values may again contribute to civic engagement (Dee, 2005; see also Green et al., 2018a, 2018b) and help build stronger communities (Brinig and Garnett, 2014). To put this in Professor Grace's own terms, as schools invest in the spiritual capital of staff, teachers, and principals, this may have lasting benefits for the schools and their students (Grace, 2002a, 2002b).

\section{Economic contributions}

There is a debate in many countries as to whether states should provide funding for low-cost nonprofit "private" ${ }^{, 5}$ schools, which would include Catholic schools. Discussing arguments related to this debate is beyond the scope of this chapter, but it should be noted that a robust network of Catholic schools, whether they benefit from public funding or not, may be beneficial to societies in several 
ways. One of them relates to savings for state budgets since in many countries parents pay some or all the cost of sending their children to Catholic schools. When this is the case, enrolment in Catholic schools reduces budget outlays that states must finance to provide basic education to children. These savings represent a shift of the economic burden of providing education to households.

To estimate education budget savings for governments from Catholic schools, information is needed on the number of children enrolled in Catholic schools and the level of funding per student provided by states to Catholic schools in comparison to funding provided to public schools. As noted earlier, information on enrolment in Catholic schools is available from the annual statistical yearbooks of the Church. Information on state funding for private and public schools is available for OECD and partner countries through data collected for Education at a Glance reports. Assuming for simplicity that Catholic schools are funded by states at the same level as other private schools (in some countries such as the United States, funding for Catholic schools is lower), the data can be combined with data on enrolment in Catholic schools to measure budget savings for states generated by Catholic schools.

Estimates for 38 OECD and partner countries suggest that, overall, budget savings from Catholic schools in these countries are valued at US\$ 63 billion per year in purchasing power parity terms (Wodon, 2019d). When comparing those estimates to those for private schools overall, Catholic schools account for 35.4 percent of the total budget savings from private schools at the primary level, and 19.2 percent at the secondary level. The country that accounts for the largest budget savings from Catholic schools is the United States, with savings valued at US\$ 12 billion for primary schools and US\$ 7 billion for secondary schools. Similar analysis for Catholic colleges and universities suggests that Catholic tertiary education institutions help generate in the same set of countries another $\$ 43$ billion in savings for state budgets versus a situation in which the students were to enrol in public institutions instead (Wodon, 2018b; see also Wodon, 2019e for estimates for all private schools as opposed to only Catholic schools).

Another way to show the economic contribution of Catholic schools is to compute the share of 'human capital' wealth created by the schools using recent World Bank data on the changing wealth of nations. ${ }^{6}$ Wealth is the assets base that enables nations to generate future income. Human capital wealth is defined as the present value of the future earnings of a country's labour force. The other two main sources of wealth are produced capital and natural capital, but human capital wealth accounts for a much larger proportion of total wealth than natural capital and produced capital (Lange et al., 2018).

To estimate the contribution of Catholic schools globally to human capital wealth, analysis can rely on an assessment of the share of human capital wealth attributed to educational attainment, and in turn the share of the contribution of Catholic schools to educational attainment. Such an analysis for 141 countries accounting for 95 percent of the world's population suggests that Catholic schools may contribute globally US\$ 12 trillion to the changing 
wealth of nations (Wodon, 2019f). The main objectives of Catholic schools are not economic, but their economic contribution for societies' development is substantial. 7

\section{Conclusion}

Building on the pioneering work of Professor Grace in exploring the role played by Catholic schools in many countries (Grace and O'Keefe, 2007), the purpose of this chapter was to document some of the contributions made by Catholic schools globally. After a brief review of global and regional trends in enrolment in K12 Catholic schools, this chapter considered three key contributions by Catholic schools: their contribution to education systems, their contribution to communities, and finally their economic contribution. These contributions are substantial and need to be better recognised.

In many ways, Catholic schools appear to have done comparatively well. But we should not forget that doing well in comparison to other types of schools does not imply doing well in absolute terms. Especially for student learning, much remains to be done, as noted by the World Bank (2018) report on the learning crisis and companion studies such as Bashir et al. (2018) for sub-Saharan Africa. In the developing world, many education systems, including in all likelihood many Catholic schools, have not yet succeeded in ensuring that all the children enrolled in school actually learn effectively. These education systems were already facing a learning crisis before the COVID-19 crisis. The challenges brought about by the current crisis on top of those that prevailed before the crisis hit are daunting. Catholic schools in countries that do not provide financial support to the schools are especially vulnerable, because the economic crisis has weakened the ability of parents to pay for the education they want to give to their children. In these countries, there is a high risk that many Catholic schools may have to close (on the threats from the current crisis and potential responses, see the analysis in Wodon, 2020e, 2020f).

It is too early at the time of writing to assess how adequate Catholic school responses as well as broader national policy responses will be to mitigate the effects of the COVID-19 crisis. For developing country contexts, which is where enrolment in Catholic schools is growing fastest, useful reviews of options for schools and education systems to cope with the current crisis have been published (see for example World Bank, 2020). Some of the lessons from those reviews are valid for developed countries as well, even if the challenges are different. Those reviews emphasise the idea of 'rebuilding better' after the crisis, for example through blended learning mixing in-person teaching with online materials. While rebuilding better will not be easy, it will be needed. Ensuring that Catholic schools can pursue their mission will be challenging, but the benefits of doing so will be reaped for many years to come.

In concluding this chapter, let me mention one last thought about Professor Grace's contribution to research on Catholic schools. At one of our meetings in 
London, I asked him why he launched ISCE in 2009. He mentioned that as he was driving one night, he had an inspiration that promoting research on Catholic schools should be his 'calling' in retirement. I guess that at the time he was still serving as Head of the School of Education at Durham University after a long teaching career among others at Kings College (London), the University of Cambridge, and Victoria University of Wellington. It seems fair to say that he never retired. Apart from founding ISCE, he remained very active in managing the Centre for Research and Development in Catholic Education, publishing books and articles, speaking on Catholic education, and even serving as a Consultor to the Congregation for Catholic Education for several years. This level of dedication to the cause of Catholic education is a great example for all of us, and especially those (including myself) who may be starting to think about 'what next' when planning their future retirement!

\section{Notes}

1 OIEC is a nonprofit that federates globally national Catholic education associations and congregations running schools, and helps represent Catholic education in international fora, including at the United Nations.

2 In the interview I did with Professor Grace for the Educatio Si Bulletin, I asked what was 'spiritual capital'. He answered that he thought about the concept after interviewing 60 Catholic headteachers working in challenging inner-city Catholic secondary schools in London, Birmingham, and Liverpool. As he explained it, 'the majority of them were possessed by what can be called a "vocation" or an "inner spiritual strength" which sustained them in the day to day challenges of their work. They characteristically related their Catholic faith to their practice in schools. As a background to my fieldwork, I had read the important work of the French social theorist Pierre Bourdieu and his valuable analytical concepts of "Social capital", "Cultural capital" and "Religious capital". However, my participants seemed to have a form of capital which was different from these and in the last chapter of my book I expressed this internal resource which they possessed as "Spiritual Capital". This was not Bourdieu's religious capital. I defined it as: "Resources of faith and values derived from commitment to a religious tradition"” (Grace, 2002b, p. 236).

$3 \mathrm{~K} 12$ refers to education from Kindergarten (pre-school) to the 12th grade or completion of high school.

4 This could be related to Grace's hypothesis about the presence of Spiritual Capital and its motivating consequences for teachers and school leaders, but more research would be needed before this relation could be demonstrated empirically.

5 Some Catholic researchers object to the use of the label 'private' for Catholic schools. Many Catholic schools began historically as 'voluntary schools'. Education was provided by religious congregations at minimal cost to parents. Today, in many countries, in part because of reductions in the numbers of Religious available as teachers, many Catholic schools are compelled to charge fees in order to survive. But they aim to maintain those fees as low as possible and they have an identity that differs substantially from traditional private schools which tend to be socially exclusive and charge high fees (although there is today also an increase in low-cost private schools especially in the developing world).

6 Human capital wealth can be estimated using household surveys by computing and discounting the stream of earnings that individuals are expected to accrue over the 
remainder of their work life, with earnings themselves modelled as a function of the individual's level of educational attainment and their work experience.

7 It is important for the Catholic Church, working through its conferences of bishops and national Catholic education associations across the world, as well as the Congregation for Catholic Education and organisations such as OIEC and the International Federation of Catholic Universities (IFCU), to bring this type of data to the attention of global leaders. This can help demonstrate how Catholic schools are contributing to the common good of the societies in which they are located. This is one of the reasons why I wrote for OIEC the first Global Catholic Education Report in 2020. The next report is planned for release in March 2021.

\section{References}

Altonji, J. G., T. E. Elder, and C. R. Taber, (2005). An Evaluation of Instrumental Variable Strategies for Estimating the Effects of Catholic Schooling, Journal of Human Resources 40, pp. 791-821.

Bashir, S., M. Lockheed, E. Ninan, and J. P. Tan, (2018). Facing Forward: Schooling for Learning in Africa. Washington, DC: The World Bank.

Black, M. M., S. P. Walker, L. C. H. Fernald, C. T. Andersen, A. M. DiGirolamo, C. Lu, D. C. McCoy, G. Fink, Y. R. Shawar, J. Shiffman, A. E. Devercelli, Q. Wodon, E. Vargas-Barón, and S. Grantham-McGregor, (2017). Early Child Development Coming of Age: Science through the Life-Course, The Lancet, 389 (10064), pp. 77-90.

Brinig, M. F. and N. S. Garnett, (2014). Lost Classroom, Lost Community: Catholic Schools' Importance in Urban America. Chicago: The University of Chicago Press.

Bryk, A. S., V. E. Lee, and P. B. Holland, (1993). Catholic Schools and the Common Good. Cambridge, MA: Harvard University Press.

Carbonaro, W., (2006). Public-Private Differences in Achievement among Kindergarten Students: Differences in Learning Opportunities and Student Outcomes, American Journal of Education, 113, pp. 31-65.

Coleman, J. S., T. Hoffer, and S. Kilgore, (1982). High School Achievement: Public, Catholic, and Private Schools Compared. New York: Basic Books.

Coleman, J. S. and T. Hoffer, (1987). Public and Private High Schools: The Impact of Communities. New York: Basic Books.

Congregation for Catholic Education, (2017). Educating to Fraternal Humanism: Building a "Civilization of Love" 50 Years after Populorum Progressio. Vatican City: Libreria Editrice Vaticana.

Dee, T. S., (2005). The Effects of Catholic Schooling on Civic Participation, International Tax and Public Finance, 12 (5), pp. 605-625.

Delfra, L. A., W. C. Mattison, S. D. McGraw, and T. S. Scully, (2018). Education in a Catholic Key, in W. H. James, editor, The Handbook of Christian Education. Hoboken, NJ: Wiley Blackwell.

Demas, A. and G. Arcia, (2015). What Matters Most for School Autonomy and Accountability: A Framework Paper. SABER Working Paper Series Number 9. Washington, DC: The World Bank.

Denboba, A., R. Sayre, Q. Wodon, L. Elder, L. Rawlings, and J. Lombardi, (2014). Stepping Up Early Childhood Development: Investing in Young Children for High Returns. Washington, DC: The World Bank. 
Elder, T., and C. Jepsen, (2014). Are Catholic Primary Schools More Effective than Public Primary Schools? Journal of Urban Economics, 80, pp. 28-38.

Evans, W., and R. Schwab, (1995). Finishing High School and Starting College: Do Catholic Schools Make a Difference? Quarterly Journal of Economics, 110, pp. 941-974.

Francis, (2015). Encyclical Letter Laudato Si' of the Holy Father Francis on Care for Our Common Home. Vatican City: Libreria Editrice Vaticana.

Freeman, K. J., and M. Berends, (2016). The Catholic School Advantage in a Changing Social Landscape: Consistency or Increasing Fragility?, Journal of School Choice, 10 (1), pp. $22-47$

Gemignani, R., and Q. Wodon (2017). Gender Roles and Girls' Education in Burkina Faso: A Tale of Heterogeneity between Rural Communities, American Review of Political Economy, 11 (2), pp. 163-175.

Gemignani, R., M. Sojo, and Q. Wodon, (2014). What Drives the Choice of Faithinspired Schools by Households? Qualitative Evidence from Two African Countries, Review of Faith \& International Affairs, 12 (2), pp. 66-76.

Grace, G., (2002a). Catholic Schools: Mission, Markets and Morality. London and New York: Routledge Falmer.

Grace, G., (2002b). Mission Integrity: Contemporary Challenges for Catholic School Leaders. In K. Leithwood and P. Hallinger, editors, Second International Handbook of Educational Leadership and Administration. Dordrecht: Kluwer Academic Press.

Grace, G., and J. O'Keefe, (Ed.), (2007). International Handbook of Catholic Education: Challenges for School Systems in the 21st Century, two volumes. New York: Springer.

Grace, G. (2020). Meet Professor Gerald Grace, Editor of International Studies in Catholic Education (Interview by Q. Wodon), Educatio Si Bulletin, Issue 3, Winter 2020, pp. 30-33.

Greeley, A. M., (1982). Catholic High Schools and Minority Students. New Brunswick, NJ: Transaction Books.

Green, B., D. Sikkema, and D. Sikkink, (2018a). Cardus Education Survey 2018: British Columbia Bulletin. Ottawa: Cardus.

Green, B., D. Sikkema, and D. Sikkink, (2018b). Cardus Education Survey 2018: Ontario Bulletin. Ottawa: Cardus.

Hallinan, M. T., and W. N. Kubitschek, (2013). School Sector, School Poverty, and the Catholic School Advantage, Journal of Catholic Education, 14 (2), pp. 498-518.

Jepsen, C., (2003). The Effectiveness of Catholic Primary Schooling, Journal of Human Resources, 38, pp. 928-941.

Lange, G. M., Q. Wodon, and K. Carey, (2018). (Eds.). The Changing Wealth of Nations 2018: Sustainability into the 21st Century. Washington, DC: The World Bank.

Lavado, P. et al. (2016). The Effect of Fe y Alegria on School Achievement: Exploiting a School Lottery Selection as a Natural Experiment. IZA Discussion Paper number 10431. Bonn, Germany: IZA - Institute of Labor Economics.

McKinney, S., (2018). The Roots of the Preferential Option for the Poor in Catholic Schools in Luke's Gospel, International Studies on Catholic Education, 10 (2), pp. 220-232.

Neal, D., (1997). The Effects of Catholic Secondary Schooling on Educational Achievement. Journal of Labor Economics, 15 (1), pp. 98-123.

Parra Osorio, J. C., and Q. Wodon, (2014). Faith-Based Schools in Latin America: Case Studies on Fe y Alegría. Washington, DC: The World Bank.

Pontifical Council for Justice and Peace, (2004). Compendium of the Social Doctrine of the Church. Vatican City: Libreria Editrice Vaticana. 
Sander, W., (1996). Catholic Grade Schools and Academic Achievement. The Journal of Human Resources, 31 (3), pp. 540-548.

Sander, W. and A. Krautmann, (1995). Catholic Schools, Dropout Rates and Educational Attainment. Economic Inquiry, 33 (2), pp. 217-233.

Secretariat of State of the Vatican, (2020). Annuarium statisticum Ecclesiae 2018 / Statistical Yearbook of the Church 2018 / Annuaire statistique de l'Eglise 2018. Vatican City: Libreria Editrice Vaticana.

Wodon, Q., (2014). Education in sub-Saharan Africa: Comparing Faith-based, Private Secular, and Public Schools. Washington, DC: The World Bank.

Wodon, Q., (2015). The Economics of Faith-based Service Delivery: Education and Health in sub-Saharan Africa. New York: Palgrave Macmillan.

Wodon, Q., (2018a). Enrollment in K12 Catholic Schools: Global and Regional Trends, Educatio Catholica, IV (3), pp. 189-210.

Wodon, Q., (2018b). Enrollment in Catholic Higher Education across Countries, Educatio Catholica, IV (4), pp. 173-195.

Wodon, Q., (2019a). Implications of Demographic, Religious, and Enrollment Trends for the Footprint of Faith-Based Schools Globally, Review of Faith \& International Affairs, 17 (4), pp. 52-62.

Wodon, Q. (2019b). Catholic Schools in Latin America and the Caribbean: Enrollment Trends, Market Share, and Comparative Advantage, Estudios sobre Educación, 37, pp. 91-111.

Wodon, Q., (2019c). How Well Do Catholic and Other Faith-based Schools Serve the Poor? A Study with Special Reference to Africa, Part I: Schooling, International Studies on Catholic Education, 11 (1), pp. 4-23.

Wodon, Q. (2019d). Pluralism, the Public Purse, and Education: An International Estimate of Savings to State Budgets from K-12 Catholic Schools, Review of Faith \& International Affairs, 17 (2), pp. 76-86.

Wodon, Q., (2019e). Budget Savings from Private Primary and Secondary Schools in OECD and Partner Countries, International Journal of Education Law and Policy, 15, pp. 29-36.

Wodon, Q., (2019f). Measuring the Contribution of Faith-based Schools to Human Capital Wealth: Estimates for the Catholic Church, Review of Faith \& International Affairs, 17 (4), pp. 94-102.

Wodon, Q. (2019g). Editorial: Education, The Rights of the Child, and Development, in A. de La Rochefoucauld and C. M. Marenghi, editors, Education as a Driver to Integral Growth and Peace - Ethical Reflections on the Right to Education, The Caritas in Veritate Foundation Working Papers. Chambésy, Switzerland: Caritas in Veritate Foundation.

Wodon, Q., (2020a). Global Catholic Education Report 2020: Achievements and Challenges at a Time of Crisis. Rome: International Office of Catholic Education.

Wodon, Q., (2020b). Enrollment in Catholic Higher Education: Global and Regional Trends, Journal of Catholic Higher Education, 39 (1), pp. 87-104.

Wodon, Q., (2020c). Are New Secondary Schools Built Where They Are Needed Most? Comparing Catholic with Public and Other Private Schools in Uganda, Review of Faith \& International Affairs, 18 (2), pp. 44-60.

Wodon, Q., (2020d). How Well Do Catholic and Other Faith-based Schools Serve the Poor? A Study with Special Reference to Africa, Part II: Learning, International Studies on Catholic Education, 12 (1), pp. 3-20. 
Wodon, Q., (2020e). Covid-19 Crisis, Impacts on Catholic Schools, and Potential Responses, Part I: Developed Countries with Focus on the United States, Journal of Catholic Education, 23 (2), pp. 13-50.

Wodon, Q., (2020f). Covid-19 Crisis, Impacts on Catholic Schools, and Potential Responses, Part II: Developing Countries with Focus on sub-Saharan Africa, Journal of Catholic Education, 23 (2), pp. 51-86.

World Bank, (2018). World Development Report 2018: Learning to Realize Education's Promise. Washington, DC: The World Bank.

World Bank, (2020). The COVID-19 Pandemic: Shocks to Education and Policy Responses. Washington, DC: The World Bank. 